Kansas State University Libraries

New Prairie Press

\title{
Patterns of Knowledge Construction
}

\author{
Bo Chang \\ University of Georgia
}

Follow this and additional works at: https://newprairiepress.org/aerc

Part of the Adult and Continuing Education Administration Commons

(c) (1) (9)

This work is licensed under a Creative Commons Attribution-Noncommercial 4.0 License

\section{Recommended Citation}

Chang, Bo (2009). "Patterns of Knowledge Construction," Adult Education Research Conference.

https://newprairiepress.org/aerc/2009/papers/16

This is brought to you for free and open access by the Conferences at New Prairie Press. It has been accepted for inclusion in Adult Education Research Conference by an authorized administrator of New Prairie Press. For more information, please contact cads@k-state.edu. 


\title{
Patterns of Knowledge Construction
}

\author{
Bo Chang \\ Department of Lifelong Education, Administration and Policy, the University of Georgia
}

\begin{abstract}
Based on Berger \& Luckmann's (1967) social constructionism framework, the purpose of this study is to identify the knowledge construction patterns and the conditions for these patterns to occur in a learning community in Shanghai, China.
\end{abstract}

In an effort to address recent social problems, China is engaged in building a harmonious society through many strategies, one of which is to develop a lifelong learning society. Influenced by the lifelong education movement, from 2001 to 2008, 114 national community pilots (Notice of the fourth list of the national community education pilots, 2008), and hundreds of local community pilots were established in China to radiate knowledge from small social units such as learning salons and learning clubs to the local communities, and further to the whole society. This kind of collective learning is gradually becoming an important topic nowadays. In collective learning, learners are immersed in the local learning context, are shaped by it and learn to improve themselves and the local community by radiating the individual knowledge to the public. Few studies examine the topic of how to learn and construct knowledge collectively in the local community. The purpose of this study is to understand how knowledge is constructed in a learning community in Shanghai, China, with two research questions (1) what are the patterns of knowledge construction? (2) Under what conditions do these patterns occur?

\section{Methodology}

I targeted one of these 114 Chinese national community pilots: the Zhabei Learning Community (the Zhabei District, one of the administrative districts of Shanghai, China). Based on the epistemology of social constructionism, an embedded case study was employed to examine learning in the Zhabei district and its nine learning cells. Administratively, the Zhabei District is divided into eight streets (the administrative divisions, similar to wards) and one town. To represent the general features of the Zhabei Learning Community, I selected nine learning cells from the northern, the middle, and the southern parts of Zhabei. Those nine learning cells, consisting of two programs, three clubs, one salon, and three organizations selected from six streets, are the embedded sub-cases. Then from within the nine learning cells, I selected four learners representing each of the following five groups: elderly people, migrant workers, unemployed workers, white-collar workers, and leaders. Participants ranged in age from 20 to 80 years old. Their education levels ranged from those having only attended middle school to those having college degrees. Observation, document, and semi-structured interviews were employed to collect data. Twenty qualified participants were interviewed for one to two hours according to a list of open-ended questions about their learning and life experiences. Data was analyzed inductively using the constant comparative method. By comparing data from those five groups of participants, six knowledge construction patterns emerged.

\section{Findings}

Six patterns of knowledge construction emerged from the data of 20 interviewees: radiation, circulation, simulation, socialization, contextualization, and composition. Based on Berger \& Luckmann's (1967) theory about how reality is constructed, circulation, simulation, 
socialization, contextualization, and composition mainly emphasize the process of knowledge creation. While radiation especially targets how created knowledge spreads to a larger social unit.

\section{Radiation}

Radiation refers to how knowledge is shared among learners and radiated from the individual learners to the public through certain tools (see figure 1). In figure 1, the dots in the inner circle refer to the individual knowledge in its learning cells. The outer circles refer to the local community and to the other outside communities. Learning experiences from Jiang, Lin, Hong, Wan and Hao showed that this pattern appeared in their learning cells. Lin, from the Ground Calligraphy Salon, described how they wrote the ground calligraphy in front of the parks and also how they expanded the ground calligraphy knowledge from the individuals to the public.

Chang: "I know that your ground calligraphy group also performed for non-profit events. I guess there must have been many interesting stories."

Lin: "Ha-ha, yeah. Too many. For example, some Chinese from England, America, and Canada told me: 'Oh, Old Mr., we saw you on TV. Oh, you are writing here. ..' Our activities were also reported in the newspaper. Some foreigners asked me to teach them how to write. Now I am the mentor of a student from America.."

Lin himself and his members extended their learning circle not only to people from a larger area in Shanghai and to people from other parts of China, but also to people from other countries as well. Lin said: "It does not matter if your calligraphy is good or not. The most important thing is that you can make friends. When I saw them (people passing by the parks), I always asked them to write. It is good." On June 3, 2008, I observed the Ground Calligraphy activity in front of Zhabei Park. I saw some calligraphers writing down some traditional Chinese classical poems and the traditional Hundred Family Names. One calligrapher there asked the people passing by the park to write on the ground. Some people did write and bought the oversized calligraphy brushes to practice. Ground calligraphy is like a bridge that connects learners and the public.

Like any other learning activities provided for the elderly, Baoshan Photography Salon in Zhabei provides a communication platform for senior citizens who are interested in photography to share their photographic knowledge with others. Jiang, the team leader of the Salon, told me they used their cameras as tools to record historical heritage and important local events, and to transfer a message of societal love and care to the disadvantaged people in a local community, and even to the people outside of the community (omit the evidence, below I only use "omit").

A migrant who married a Shanghainese, Hong from the Sisters Club, excitedly described her special experience of learning the Shanghai dialect. To learn the Shanghai dialect is not just to learn a survival skill in the competitive Shanghai society. Her learning experience was broadcast via $\mathrm{TV}$, which significantly influenced her view about the future. Through the medium of TV, she realized how important knowledge could be in her development process. She felt that knowledge could change her social status, and could help to increase her quality of life. Hong 's learning experience is not only an individual activity; it was shared with the pubic through a TV report. This motivated more and more migrants to learn. Many migrant workers in China do not have ambitious dreams for their future. Living in big cities like Shanghai, they work hard for their living. Hong's story about how her learning experience changed her life was broadcast on TV and influenced other migrants too. Some migrants realized how important knowledge could be in improving their lives and would like to follow Hong as their model.

The three examples above show how individual learning not only enriched the individual learners' lives; it also radiated to the public and became a collective activity influencing the people in or outside of the community. Culture products such as ground calligraphy, newspapers, 
photography, and television play an important role in radiating a new belief, a new message, and new knowledge from individuals to the public. This radiating process binds the individuals and the public together and creates an atmosphere of trust and harmony in the local community.

Conditions: In order for this pattern to occur, there are four requirements: (1) free access to the local learning resources; (2) public communication platforms and tools; (3) a shared theme or topic connecting the learners and the public together; (4) a loose and open learning structure.

\section{Circulation}

Circulation emphasizes how people gain certain knowledge by accessing all of its dimensions/profiles and circulating around its multiple mini-knowledge bases. In figure 2 , the dots refer to the multiple dimensions/profiles of knowledge. The arrows refer to the process of going through every dimension/profile of the knowledge. Learning experiences from 10 participants show that this pattern occurred in their learning cells.

Figure 1: Radiation

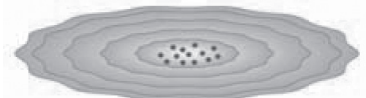

Figure 2: circulation

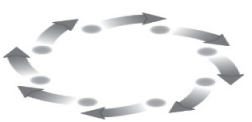

Figure 3: Simulation

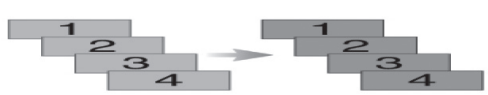

In Zhabei, the government organized a free one-day trip to Shanghai for migrant workers as part of the activities to get the migrants involved in Shanghai life. This excursion provided a good opportunity for the migrant workers to get to know Shanghai from different angles. Hong, from the Sisters Club, described how she got to know Shanghai through this type of one-day trip (omit).This one day trip enabled these migrant workers to imbibe Shanghai's history and also facts about modern Shanghai by going sightseeing and visiting different areas of the city. Every area of Shanghai, such as the Bund Sightseeing Tunnel and The Shanghai Urban Planning Exhibition Hall embodies one particular knowledge base of Shanghai. For example, the Bund Sightseeing Tunnel represents high technology and the modern style of metropolitan Shanghai. The Shanghai Urban Planning Exhibition Hall deposits the historical documents of Shanghai. These field trips are like a living knowledge that is directly and strongly presented in front of these migrants who seldom have an opportunity to involve in the society of Shanghai. More important is the fact that the organizers connected this entertainment trip together with a purposeful interpretation, which enabled the migrants to better understand the background knowledge behind all of the sightseeing.

Shen, a male migrant worker attending the New Shanghainese Club, told me how the Dragon Dance, one part of their activities in the club, took him to different places in Shanghai and increased his knowledge about Shanghai and his confidence to live in Shanghai. He said: We were invited by a boss from Wenzhou to perform the Dragon Dance to celebrate the opening ceremony of his enterprise... Even if he would not have paid me, I still would have wanted to go. For us migrant workers, we may never have such an opportunity in our life to visit such a place. .. When we fist stepped into this city, we got totally lost. Sometimes we felt scared. For Shen, the Dragon Dance as an interaction tool enabled him to visit different places such as luxurious hotels, various exhibitions, and to experience the social life that the upper class society enjoyed. These experiences of traveling around to different places and experiencing the social life of Shanghai introduced the different profiles of Shanghai to the migrant workers. Migrant workers like Shen not only know Shanghai better now, but have increased their confidence in being a part of this metropolis that was once out of reach from their world.

Wan vividly described how she learned a whole package of policies about employment through dealing with a large employment case that occurred in a complicated situation. This case was like a knowledge database of employment that covered most of the relevant employment 
policies. After Wan finished this case, she said she had gone through most of the policies on employment and gained the systematic knowledge about employment policies.

Conditions: (1) focus on the same theme to organize a series of learning activities and to address the multiple dimensions of that certain knowledge; (2) the similar activities can be reorganized to help learners access to the multi-mini-knowledge base of the new knowledge.

\section{Simulation}

Simulation emphasizes how people gain knowledge through a process of observation, imitation, and adaptation. In figure 3, No. 1, 2, 3 and 4 on the left side refer to a whole package of imitated knowledge. No. 1, 2, 3, and 4 on the right side refer to a whole package of new simulated knowledge. The arrow refers to the process of observation, imitation, and adaptation to the new context. This pattern occurred in the learning cells that 13 participants attended. Xing and Qiong mentioned that they improved their professional skills by observing the other professional teams, and adapting their skills according to their own situation. Qiong said that after he observed the catwalk by the Elderly people from the Jing'an district, he finally understood why he could not make a good turn in some catwalks. He said everyone is different; and that the instructor could only give one the general rules about the walk, which sometimes might not be appropriate for some learners. Observing other groups' catwalk enabled him to see clearly what steps he missed. In order to simulate knowledge well, Qiong said that the learners should have a similar level of knowledge as the observed people. Xing's experience reflected this point. She said that she had a very good ability to imitate. However, she still could not understand why she failed to imitate some steps sometimes, the cause of which might be her misinterpreting some steps and imitating some steps in the wrong direction. It is necessary, therefore, for the learners to have a similar level of knowledge as those whom they are imitating. If not, communication is necessary to solve the problem of misunderstanding.

Some strategies are required for good communication. Xing said because of the yearly competitive evaluation of the Chorus groups in Zhabei, the Chorus groups in different streets rarely communicate with each other. Thus, they had to learn from the other groups through observation. Hu told me that she has no problem in communicating with her colleagues from other streets because they are from different organizations and there is no conflict of interest between them. Gu said that his mentors happily showed him their tacit knowledge because they have complimentary knowledge and they feel comfortable "imitating" knowledge from each other. Chau provided another take on this issue. He said in order for mentors to voluntarily communicate their special tacit knowledge with their apprentices, the Shanghai H.B. Power Co. would reward the mentors when their apprentices gain the special knowledge, and would cancel the mentors' bonus if their apprentices worked poorly. Usually the mentors were much older than the apprentices were and would retire soon. They would feel much more comfortable sharing whatever they know without perceiving threats. Chau also used his experience to indicate that trust, respect, and love are the important factors which enable mentors to show their apprentices their tacit knowledge. He said, "I treated my mentor like my father, and he treated me like his son. Which father would not like to impart to his son the special skills that he has?"

Conditions: (1) have similar structures between the imitated object and the new simulated object; (2) understand the whole package (for example, 1, 2, 3 and 4 in figure 3 ) of the imitated objects instead of only part of them; (3) make sure that the observers have a similar level of knowledge as that of the observed; (4) ensure sufficient communication (4) provide a safe and trusting learning environment.

Socialization 
Socialization emphasizes how people are involved in, adapted to and accepted by the changed socio-cultural context, and are molded by certain directions through selectively learning specific beliefs, attitudes, knowledge, perceptions, skills, and certain experiences. In figure 4, the first figure refers to the learners in their original context. The second figure refers to the learners in a changed context; the third figure refers to the learners that have already adapted to a new context. The arrows refer to the influencing factors imposing on the learners. When the context changes dramatically, the influencing factors will become dramatic and will direct or even "force" the learners to change.

Nine participants experienced socialization. It was especially dramatic on Sun, Hong, and Shen. Sun, who worked for nine years at one company in Shanghai before the 1992 Business Reform, told me how he has been pushed and shaped by the quick social changes since 1992. Sun: Based upon my personality, I wanted to work (within one field) until I become old.

Bo: Then why did you job-hop?

Sun: The national system reform (1992 business reform)...In 1992, those who had worked for less than ten years were totally laid-off, no matter whether you were excellent or not....1992 was a big social change, a turning point...in the past two years, the pace of reform has become quicker and quicker, like a wheel, which started to turn in 1992, and that is now turning quicker and quicker until now.

Before 1992, Sun enjoyed a stable career at one company. Like many other Shanghainese of his age, he did not think it was necessary for him to get a college degree. After 1992, he was laid off due to the business reform in Shanghai and was tired of chasing after the changed society. He worked for one and a half years in a real estate company ran by a friend, then he left to help his brother run an international business for another one and a half years. Then he changed jobs again and worked for the N.J. Restaurant for six months. He felt he was drifting along the flood of the reforms and could not find his own position in society. He said, "It is not what I want to do, but what I can do," which vividly described how he attempted to adapt to the changes in society. "It is just not going that smoothly. When you walk in this direction, it seems there's something missing; when you walk that way, another thing is missing too," he said. He could not find the key to adapt to this changed society. Social reforms broke Sun's stable life and his previous knowledge base. He tried very hard to dance with the rhythms of the social changes, and he changed his jobs from one field to another. He did not find out what kind of knowledge or skills he needed to learn in order to adapt to this new, changed society. Basically, he lost his way in his socialization process without participating in the supportive learning programs.

Hong, a shop assistant, especially mentioned how she used the language she learned from the Sisters Club as an important tool to be involved in Shanghai society:

"When you go shopping, they hear what you say (in Mandarin). Oh, they know you are outsider, they will rip you off, and the price will be higher. If they hear you speak Shanghai dialect, they will treat you better...Even if they know you are a migrant, if they hear you are speaking the Shanghai dialect, they know you have lived in Shanghai for quite a long time, and know you know things well, he dares not cheat you, right? This is from a very practical point of view. I said: A'La (Shanghai dialect for "I am") Shanghainese.(Laugh), I pretended (to be a Shanghainese), right? Some people just want to bargain the prices with you and flatter you. Oh, I tell you!"

Shanghai society, which developed its own institutionalized norms and culture, differentiated outsiders from the local Shanghainese through the use of the Shanghai dialect. People speaking the same language are included in the same cultural community and share the similar tacit knowledge embedded in the daily life practices. Participating in the Shanghai dialect program and other migrant programs provided by the Sisters Club enabled Hong to become 
successfully involved in Shanghai daily life practices. She was informed of the Shanghai culture and norms embedded in those daily life practices and was proud of being one of the Shanghainese. The urge to be involved in Shanghai society, to be adapted to it and finally to be accepted as one part of it, directed Hong to learn the Shanghai dialect and to use the new language as a tool to reframe her new social roles and positions in Shanghai. However, not every learning program aiming at socialization resulted in a positive outcome. (omit) Sheng's negative impression about traditional bureaucracy occurred after he experienced some bureaucratic learning activities, which spoiled the good image of Shanghai he had built up through a series of previous socialized activities. Basically his socialization process backfired.

Conditions:(1) the learners should be involved in the new context (2) the learners should identify the gap between their previous knowledge and the knowledge required by the new context, and be able to fill this gap; (3) the message of socialization should be consistently supported in the learning process.

\section{Contextualization}

Contextualization refers to learning or creating new knowledge by engaging in and adapting to the authentic resources, materials, and the culture of the local context(see figure 5) (omit).

Figure 4: Socialization Figure 5 Contextualization. Figure 6 Composition
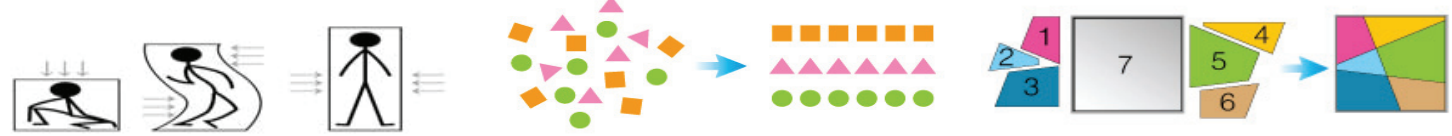

\section{Composition}

Composition emphasizes how people create knowledge by embedding all of the particles of knowledge into one package with one identical format or theme(see figure 6) (omit)

\section{Conclusion}

The aim of the Zhabei learning community is to create a lifelong learning environment for its local people. Focusing on the discourse of creating a harmonious lifelong learning community, the government built the administrative and professional networks from the top down, nurtured the non-governmental organizations, the learning groups and the learning cells from the grass roots, and guided the direction of the learning community through multiple strategies such as evaluation, project bidding, and community services. To explore the local knowledge, the Zhabei Learning Community embraced the community issues, community heritage and resources in the learning activities and formulated the core learning activities. Six knowledge construction patterns occurred in this lifelong learning community, which in return contributed to the local community development.

\section{References}

Berger, P. L., \& Luckmann, T. (1967): The social construction of reality: A treatise in the sociology of knowledge. New York: Anchor Books. 